\title{
PENINGKATAN PENGETAHUAN PENYUSUNAN SOAL BERBASIS HOTS PADA GURU BAHASA INGGRIS SMA NEGERI 1 KOTAGAJAH
}

\author{
Dian Puspita $^{1)}$, Berlinda Mandasari ${ }^{2)}$, Kamelia Sari ${ }^{3)}$ \\ Program Studi Sastra Inggris dan Pendidikan Bahasa Inggris, \\ Universitas Teknokrat Indonesia (UTI) Lampung, Indonesia \\ e-mail: dian.puspita@teknokrat.ac.id
}

\begin{abstract}
One indicator of the success of education is the good quality of teachers. Permendiknas Number 16 of 2007 concerning Academic Qualification Standards and Competency of Subject Teachers states that teachers must have competencies, one of which is the competence to develop assessment instruments, both assessment of learning processes and assessment of learning outcomes. This is very important to measure the learning outcomes that have been set in the curriculum. In fact, English teachers at SMA Negeri 1 Kotagajah were still lacked in compiling exam questions using HOTS criteria. Therefore, the training program to create HOTS based test for English teachers at SMA Negeri 1 Kotagajah was implemented. Based on the results of the pre-test and post-test conducted, it was found that there was an increase in knowledge about the preparation of HOTS-based questions by the English teacher of SMA Negeri 1 Kotagajah.
\end{abstract}

KEYWORDS: English, HOTS, Assessment Instrument

\begin{tabular}{|c|c|c|}
\hline Accepted: & Reviewed: & Published: \\
December 30 2020 & January 13 2021 & February 15 2021 \\
\hline
\end{tabular}

\section{PENDAHULUAN}

Pendidikan merupakan suatu upaya yang dilakukan guna meningkatkan kualitas sumber daya manusia. Dalam pelaksanaannya, keberhasilan pendidikan dipengaruhi oleh berbagai faktor. Salah satu faktor penting dalam keberhasilan pendidikan adalah sumber daya guru yang mumpuni. Guru sangat berpengaruh di dalam proses pendidikan dari awal hingga akhir. Oleh karena itu, untuk menjamin mutu guru, pemerintah telah mengeluarkan Permendiknas Nomor 16 Tahun 2007 tentang Standar Kualifikasi Akademik dan Kompetensi Guru Mata Pelajaran (Sudibyo \& Bambang, 2007). Dalam peraturan ini, dinyatakan bahwa guru harus memiliki kompetensi, salah satunya adalah kompetensi 
mengembangkan instrumen penilaian, baik penilaian proses belajar maupun penilaian hasil belajar. Hal ini sangat penting untuk mengukur capaian pembelajaran yang telah ditetapkan dalam kurikulum.

Berdasarkan Kurikulum 2013, tujuan pendidikan menitikberatkan pada kemampuan siswa untuk dapat melakukan observasi, bertanya, bernalar, dan mengomunikasikan apa yang mereka pelajari (Peraturan Menteri Pendidikan Dan Kebudayaan Republik Indonesia Nomor 58 Tahun 2014, 2018). Tujuan pendidikan juga mengacu kepada pembentukan kompetensi peserta didik untuk dapat menghadapi tantangan di kehidupan nyata, baik tantangan internal maupun tantangan eksternal. Pada tantangan eksternal, globalisasi merupakan faktor terbesar yang dapat menjadi ancaman bagi calon lulusan yang tidak memiliki kompetensi, ataupun dapat pula menjadi peluang bagi mereka yang memiliki kompetensi. Oleh karena itu, kemajuan pendidikan harus diutamakan guna menjawab tantangan ini. Salah satu faktor penentu keberhasilannya pendidikan adalah sistem evaluasi.

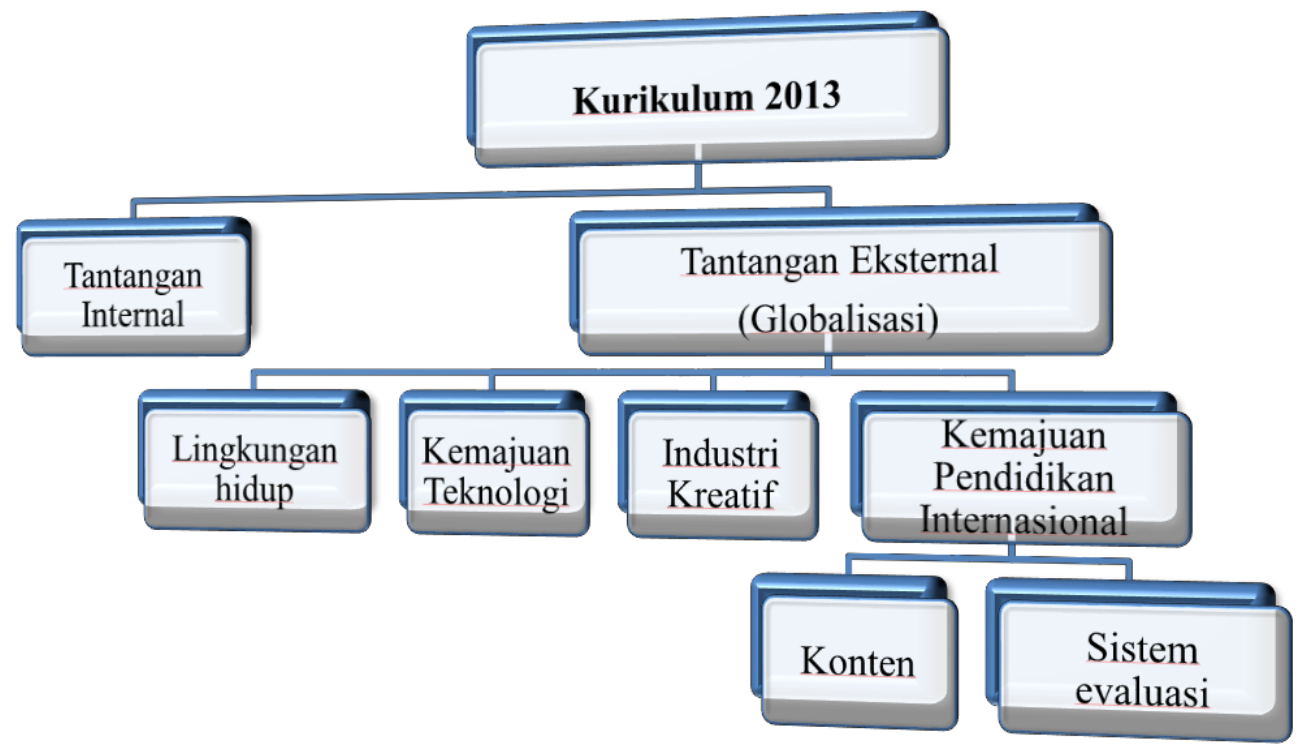

Gambar 1. Fokus Tujuan Pendidikan Kurikulum 2013

Kurikulum 2013 juga merupakan upaya pemerintah untuk mempersiapkan generasi yang memiliki kecapakan yang dibutuhkan pada abad 21 sehingga memiliki daya saing yang tinggi (Zubaidah, 2016). Menghadapi perkembangan zaman dan juga era globalisasi, generasi muda harus dipersiapkan untuk menghadapi tantangan yang kompleks, sehingga mereka membutuhkan 
beberapa kompetensi kemampuan berpikir kritis, kreatif, komunikatif dan kolaboratif. Kemampuan untuk menerapkan pengetahuan yang mereka dapatkan melalui proses pendidikan ke dalam konteks kehidupan nyata serta pada situasi yang masih asing juga merupakan tujuan yang harus dicapai dalam pendidikan. Melalui pendidikan, kemampuan ini dapat dibentuk melalui pemecahan masalah yang memiliki kriteria higher-order thinking skills (HOTS) (OECD, 2012).

HOTS memiliki kriteria berpikir tingkat tinggi seperti kemampuan menemukan, menganalisis, menciptakan metode baru, merefleksi, mempredisksi, berargumen, dan mengambil keputusan yang tepat. Kriteria-kriteria tersebut seringkali disalahartikan sebagai karakter "sulit". Padahal, hal yang digarisbawahi pada HOTS bukanlah tingkat kesulitan soal, melainkan adanya proses bernalar. Dalam taksonomi Bloom, HOTS terletak pada proses kognitif yang tertinggi seperti yang tergambar pada tabel berikut.

\section{Tabel 1. Dimensi Proses Kognitif HOTS berdasarkan Taksonomi Bloom}

(Anderson \& Krathwohl, 2001)

\begin{tabular}{|c|c|c|}
\hline \multirow{3}{*}{ HOTS } & Mengkreasi & $\begin{array}{l}\text { - Mengkreasi ide/gagasan sendiri. } \\
\text { - Kata kerja: mengkonstruksi, desain, kreasi, mengembangkan, } \\
\text { menulis, memformulasikan. }\end{array}$ \\
\hline & Mengevaluasi & $\begin{array}{l}\text { - Mengambil keputusan sendiri. } \\
\text { - Kata kerja: evaluasi, menilai, menyanggah, memutuskan, } \\
\text { memilih mendukung. }\end{array}$ \\
\hline & Menganalisis & $\begin{array}{l}\text { - Menspesifikasi aspek-aspelo elemen. } \\
\text { Kata kerja: membandingkan, memeriksa, , mengkritisi, } \\
\text { menguji. }\end{array}$ \\
\hline \multirow{2}{*}{ MOTS } & Mengaplikasi & $\begin{array}{l}\text { - Menggunakan informasi pada domain berbeda } \\
\text { - Kata kerja: menggunakan, mendemonstrasikan, } \\
\text { mengilustrasikan, mengoperasikan. }\end{array}$ \\
\hline & Memahami & $\begin{array}{l}\text { - Menjelaskan ide/konsep. } \\
\text { - Kata kerja: menjelaskan, mengklasifikasi, menerima, } \\
\text { melaporkan. }\end{array}$ \\
\hline LOTS & Mengetahui & $\begin{array}{l}\text { - Mengingat kembali. } \\
\text { - Nata ker|a: mengingar, mencarar, menguang, menirukan. }\end{array}$ \\
\hline
\end{tabular}

Berdasarkan urgensi HOTS serta relevansinya dengan tujuan Kurikulum pendidikan yang dianut oleh Indonesia, maka kemampuan guru menyusun soalsoal yang memiliki kriteria HOTS menjadi hal yang mutlak. Hal ini juga selaras dengan World Bank Report (2018) pada Training Teachers on the Job (Popova et al., 2016) yang menyatakan bahwa guru tidak hanya membutuhkan pelatihan pedagogi, tetapi juga membutuhkan pelatihan dalam menyusun soal-soal 
51 | Peningkatan Pengetahuan Penyusunan Soal Berbasis HOTS Pada Guru Bahasa Inggris SMAN 1 Kotagajah

berkriteria HOTS yang akan menstimulus dan membentuk kemampuan berpikir kritis siswa.

HOTS sangat penting untuk semua bidang seperti matematika, sains, sosial, dan bahasa (Assaly \& Smadi, 2015). Akan tetapi, pembelajar bahasa juga dituntut untuk memiliki kemampuan HOTS. Hal ini dikarenakan kemampuan HOTS akan membantu mereka untuk memahami bukan hanya bahasa yang mereka pelajari, tetapi juga isu-isu tren dunia. Hal ini selaras dengan hasil penelitian yang dilakukan oleh Toyoda (2015) yang menyatakan bahwa kemampuan HOTS dapat berpengaruh kepada kemampuan pembelajar bahasa kedua. Dalam konteks pendidikan di Indonesia, urgensi kemampuan HOTS pada pembelajar bahasa kedua terdapat pada subjek bahasa Inggris.

\section{METODE PELAKSANAAN}

Pelatihan ini akan dilaksanakan di SMA Negeri 1 Kotagajah. Subjek dalam penelitian ini adalah lima guru bahasa Inggris di sekolah tersebut. Kegiatan dalam pelatihan ini dibagi dalam beberapa tahapan, yaitu pengumpulan data awal, perancangan pelatihan, pelaksanaan pelatihan, evaluasi pelatihan dan follow up.

\section{Pengumpulan Data Awal}

Observasi dilakukan untuk pengumpulan data awal dan dilakukan kepada guru bahasa Inggris SMA Negeri 1 Kotagajah. Selain observasi, dilakukan wawancara kepada para subjek untuk mengetahui apakah subjek pernah mendapatkan pelatihan pembuatan soal HOTS sebelumnya.

\section{Perancangan Pelatihan}

Pelatihan dirancang berdasarkan kebutuhan mitra dan tujuan dari pengabdian yaitu meningkatkan pengetahuan dan keterampilan guru dalam menyusun soal HOTS.

\section{Pelaksanaan Pelatihan}

Kegiatan direncanakan sebanyak lima pertemuan di SMA Negeri 1 Kotagajah. Pelatihan akan dilakukan oleh peneliti dan tim. Setiap kegiatan akan diobservasi untuk melihat perkembangan peserta.

\section{Evaluasi}

Evaluasi dilakukan terdapat proses pelatihan pembuatan soal HOTS. Apabila terjadi kendala teknis dalam proses, maka alternatif-alternatif lain dapat dilakukan guna menjamin proses berjalan dengan baik. 


\section{Follow up}

Setelah dinyatakan valid, soal tersebut kemudian diujikan kepada siswa SMA Negeri 1 Kotagajah. Hasil tes kemudian dianalisis untuk mengetahui reliabilitas, daya pembeda, dan tingkat kesukaran soal.

\section{HASIL DAN PEMBAHASAN}

\section{Peningkatan Pengetahuan Guru Bahasa Inggris}

Setelah melakukan pre-test dan post-test untuk mengetahui pengetahuan guru bahasa Inggris mengenai soal berbasis Higher Order Thinking Skills (HOTS), diperoleh data mengenai peningkatan rata-rata hasil tes. Peningkatan nilai pre-test dan post-test dapat dilihat pada tabel berikut ini.

Tabel 2. Hasil Pre-test dan Post-test

\begin{tabular}{lr}
\hline \multicolumn{2}{c}{ Pre-test } \\
\hline \\
\\
Mean & 7 \\
Standard Error & 0,316228 \\
Median & 7 \\
Mode & 7 \\
Standard Deviation & 0,707107 \\
Sample Variance & 0,5 \\
Kurtosis & 2 \\
Skewness & 0 \\
Range & 2 \\
Minimum & 6 \\
Maximum & 8 \\
Sum & 35 \\
& \\
Count & 5
\end{tabular}

Post-Test

\begin{tabular}{lr} 
Mean & 8,4 \\
Standard Error & 0,244949 \\
Median & 8 \\
Mode & 8 \\
Standard Deviation & 0,547723 \\
Sample Variance & 0,3 \\
Kurtosis & $-3,33333$ \\
Skewness & 0,608581 \\
Range & 1 \\
Minimum & 8 \\
Maximum & 9 \\
Sum & 42 \\
Count & 5 \\
\hline
\end{tabular}

Berdasarkan hasil deskriptif statistik di atas, dapat dilihat bahwa terdapat peningkatan nilai rata-rata dari pre-test dan post-test yakni dari nilai rata-rata 7 menjadi 8,4. Untuk persebaran data, terdapat perbedaan dari pre-test dan posttest. Pada hasil pre-test, standar deviasi $(0,70)$ menunjukkan bahwa persebaran data lebih luas dibandingkan dengan persebaran data pada post-test $(0,54)$. Hal 
ini juga terlihat dari nilai tertinggi dan terendah dari kedua tes. Pada pre-test nilai terendah adalah 6 dan nilai tertinggi adalah 8. Sedangkan pada post-test nilai terendah mengalami peningkatan yakni 8 , dan nilai tertinggi juga mengalami peningkatan yakni 9.

\section{Persepsi Guru Bahasa Inggris Terhadap HOTS dan Pelatihan Penyusunan Soal Bahasa Inggris Berbasis HOTS}

Berdasarkan hasil evaluasi terhadap proses pelaksanaan pelatihan, diperoleh beberapa persepsi guru akan soal berbasis HOTS dan juga kaitannya dengan mata pelajaran bahasa Inggris.

a. Pengetahuan mengenai implementasi HOTS pada evaluasi pembelajaran

Berdasarkan hasil wawancara kepada seluruh guru peserta pelatihan, diketahui bahwa para guru pada dasarnya telah mengetahui kebijakan atau peraturan yang mengatur sistem penilaian pada proses pembelajaran. Akan tetapi, sebagian dari mereka tidak dapat menyebutkan peraturan Menteri yang mana yang mengatur hal tersebut.

b. Persepsi mengenai karakteristik HOTS

Meskipun berdasarkan hasil pre-test diketahui bahwa tidak semua guru mengetahui seluruh kriteria HOTS, pemahaman yang lebih baik diperoleh setelah pelatihan penyusunan soal berbasis HOTS dilaksanakan. Guru lebih memahami karakteristik-karakteristik apa saja yang perlu diperhatikan pada saat penyusunan soal. Berdasarkan hasil diskusi, guru telah memahami arah kebijakan tujuan pendidikan yakni menitikberatkan pada kemampuan siswa untuk dapat melakukan observasi, bertanya, bernalar, dan mengomunikasikan apa yang mereka pelajari. Oleh karena itu, para guru menyetujui dan memahami bahwa karakteristik yang ada pada HOTS harus tercermin pada evaluasi pembelajaran. Namun, pada kenyataannya, para guru terkadang masih menghadapi kesulitan menentukan soal seperti apa yang memiliki kriteria HOTS.

c. Sikap guru terhadap masalah penyusunan soal berbasis HOTS

Soal berbasis HOTS pada mata pelajaran bahasa Inggris pada dasarnya telah banyak diimplementasikan pada tingkat menengah atas. Akan tetapi, dengan berbagai bentuk soal yang disiapkan oleh guru, sebagian guru merasa menghadapi lebih banyak masalah pada saat menyusun soal dengan bentuk pilihan ganda dengan karakteristik HOTS. Untuk keempat skills yang diujikan 
pada mata pelajaran bahasa Inggris, para guru mengalami kesulitan yang lebih besar pada penyusunan soal writing, khususnya adalah grammar. Para guru juga memahami untuk dapat mempermudah mengidentifikasi jenis soal HOTS, terdapat beberapa kata kunci perintah yang dapat digunakan pada soal dengan prinsip mengkreasi, mengevaluasi, dan menganalisis.

d. Sikap guru terhadap pelatihan penyusunan soal berbasis HOTS

Berdasarkan hasil wawancara terhadap evaluasi pelatihan penyusunan soal berbasis HOTS, diketahui bahwa sebagian besar guru merasa mendapat manfaat yang berarti dan juga penyegaran karakteristik HOTS. Sebagian besar telah mengikuti pelatihan HOTS sebelumnya pada jangka waktu yang sedikit lama. Sedangkan bagi guru-guru baru, mereka belum pernah mengikuti pelatihan penyusunan soal berbasis HOTS.

\section{SIMPULAN}

Dari hasil pelaksanaan pelatihan soal berbasis HOTS yang dilakukan untuk guru Bahasa Inggris SMA N 1 Kotagajah, diketahui bahwa terdapat peningkatan pengetahuan guru akan HOTS dan kriterianya. Persepsi guru terhadap HOTS adalah positif. Para guru menyetujui dan memahami tujuan dan kriteria HOTS yang selaras dengan tujuan pendidikan di Indonesia. Sikap guru terhadap pelatihan penyusunan soal berbasis HOTS juga positif. Peserta menyebutkan bahwa pelatihan memberikan dampak positif terhadap pengetahuan mereka akan HOTS meskipun pelatihan penyusunan soal bersama diharapkan dapat dilakukan secara lebih intensif.

\section{DAFTAR RUJUKAN}

Anderson, L. W., \& Krathwohl, D. R. (2001). Lorin W. Anderson, David R. Krathwohl - A taxonomy for learning teaching and assessing_a revision of Bloom`s taxonomy of educational objetives-Longman. In Bookl.

Assaly, I. R., \& Smadi, O. M. (2015). Using bloom's taxonomy to evaluate the cognitive levels of master class textbook's questions. English Language Teaching, 8(5), 100-110. https://doi.org/10.5539/elt.v8n5p100

OECD. (2012). PISA 2009 Results: What Students Know and Can Do. In PISA 2009 Results: What Students Know and Can Do: Vol. I. https://doi.org/10.1787/9789264188716-ar

Peraturan Menteri Pendidikan Dan Kebudayaan Republik Indonesia Nomor 58 Tahun 2014. (2018). Peraturan Menteri Pendidikan Dan Kebudayaan 
55 | Peningkatan Pengetahuan Penyusunan Soal Berbasis HOTS Pada Guru Bahasa Inggris SMAN 1 Kotagajah

Republik Indonesia Nomor 58 Tahun 2014. Sereal Untuk.

Popova, A., Evans, D. K., \& Arancibia, V. (2016). Training Teachers on the Job: What Works and How to Measure It. Training Teachers on the Job: What Works and How to Measure It, September 2016.

https://doi.org/10.1596/1813-9450-7834

Sudibyo, \& Bambang. (2007). PERATURAN MENTERI PENDIDIKAN NASIONAL REPUBLIK INDONESIA NOMOR 16 TAHUN 2007 TENTANG STANDAR KUALIFIKASI AKADEMIK DAN KOMPETENSI GURU. In PERATURAN MENTERI PENDIDIKAN NASIONAL REPUBLIK INDONESIA NOMOR 16 TAHUN 2007.

Toyoda, E. (2015). Relationship between higher-order thinking skills and L2 performance. Electronic Journal of Foreign Language Teaching.

Zubaidah, S. (2016). KETERAMPILAN ABAD KE-21: KETERAMPILAN YANG DIAJARKAN MELALUI PEMBELAJARAN. Seminar Nasional Pendidikan. 